\begin{tabular}{|c|c|c|}
\hline 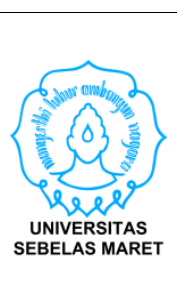 & $\begin{array}{l}\text { DWIJA CENDEKIA: Jurnal Riset Pedagogik 3 (1) (2019) 30-42 } \\
\text { DWIJA CENDEKIA } \\
\text { Jurnal Riset Pedagogik }\end{array}$ & 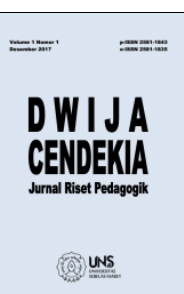 \\
\hline & https://jurnal.un & \\
\hline
\end{tabular}

\title{
Penerapan Project Based Learning dalam Mata Kuliah Penelitian Tindakan Kelas
}

\section{Chrisnaji Banindra Yudha}

STKIP Kusuma Negara

chrisnaji_by@stkipkusumanegara.ac.id

\section{Sejarah Artikel}

diterima 11/07/2019

\begin{abstract}
The research aims to improve students' ability in writing paper in the Classroom Action Research (CAR) subject using Project-Based Learning (PBL). The research subjects are the students of Elementary School Training Teacher in the First Semester of Academic Year 2018/2019. It is Classroom Action Research collaboratively. Data collection techniques use qualitative descriptive analysis techniques. The results show that the PBL model can improve the ability in writing papers. The first cycle is $61.87 \%$, the second cycle is $83.03 \%$, and third cycle is $87 \%$. It concludes that the students have ability in writing CAR with the rules listed in the research indicators and PBL is as an alternative method for delivering CAR subject to the students.

Keywords: project-based learning, classroom action research, writing ability

Abstrak

Penelitian ini bertujuan untuk meningkatkan kemampuan menulis karya ilmiah mahasiswa pada mata kuliah Penelitian Tindakan Kelas menggunakan Project Based Learning (PBL) pada Mahasiswa PGSD Semester Ganjil Tahun Akademik 2018/2019. Penelitian ini adalah penelitian tindakan kelas (Classroom Action Research) secara kolaboratif. Teknik pengumpulan data menggunakan teknik analisis deskriptif kualitatif..Hasil penelitian menunjukkan bahwa model PBL dapat meningkatkan kemampuan menulis karya ilmiah. Peningkatan tersebut pada siklus 1 sebesar $61,87 \%$, Siklus 2 sebesar $83,03 \%$ dan Siklus 3 sebesar $87 \%$. Berdasarkan hasil penelitian tersebut, Implikasi penelitian menunjukkan bahwa mahasiswa mampu untuk menulis PTK sesuai dengan kaidah-kaidah PTK yang tercantum dalam indicator penelitian dan sebagai alternative metode untuk menyampaikan perkuliahan PTK pada Mahasiswa Prodi PGSD.

Kata kunci: project based learning, penelitian tindakan kelas, kemampuan menulis
\end{abstract}

e-ISSN 2581-1835

p-ISSN 2581-1843

This work is licensed under a Creative Commons Attribution-ShareAlike 4.0 International License. 


\section{PENDAHULUAN}

Program Studi Pendidikan Guru Sekolah Dasar (Prodi. PGSD) dalam proses pembelajarannya akan mencetak calon guru sekolah dasar (SD). Dalam proses pembelajarannya, tidak hanya menekankan pada kecerdasan, inovasi, kritis dan kreatif, akan tetapi penekankan pada penanaman nilai karater yang luhur juga diperlukan. Dalam menerapkan kurikulum pembelajaran, harus sesuai dari aturan pemerintah atau Kementerian Riset dan Tekonologi Pendidikan Tinggi. Para calon guru SD atau mahasiswa PGSD dalam menempuh pembelajaran di Kampus hendaknya dibekali dengan keterampilan yang serba bisa dan mumpuni. Dengan demikian calon guru SD yang dilahirkan oleh Prodi PGSD, akan tangguh dan memiliki jiwa pendidik yang luhur.

Pada kenyataannya sebagian besar mahasiswa PGSD kelas 6B memiliki kemampuan menulis karya ilmiah yang rendah. Rendahnya terlihat saat dosenmengkroscek proposal penelitian tindakan kelas masing-masing mahasiswa. Mahasiswa dalam menyusun proposal Penelitian Tindakan Kelas (PTK) tersebut, belum ditemukan Struktur/Logika Penulisan yang jelas; dalam mengkutip teori, Kedalaman dan keluasan teori keilmuan yang relevan tidak tampak dan terkesan pada bagian teori adalah kumpulan teori-teori yang tidak ada hubungannya dengan judul proposalnya. Dalam menyusun Argumentasi teori untuk menyusun kerangka berpikir belum sesuai dengan alur ptk; dikarenakan banyak sumber yang tidak dituliskan, terkesan Orisinalitas tulisan PTK mahasiswa yang rendah; mahasiswa belum terlihat dalam mengutip teori yang relevan dengan bidang PTK yang dimiliki.

Mahasiswa PGSD harus terampil dalam menulis karya ilmiah. Menulis memiliki banyak manfaat diantaranya meningkatkan kecerdasan, pengembangan daya inisiatif dan kreativitas, penumbuhan keberanian dan motivasi dan kemampuan mengumpulkan informasi.

Menurut Dalman

(2014:3)

menulis sangat penting karena menulis merupakan sebuah proses menuangkan gagasan dalam bentuk bahasa tulis dalam tujuan, misalnya memberitahu, meyakinkan, atau menghibur. Menurut Tarigan (2013:3) menulis merupakan suatu keterampilan berbahasa yang dipergunakan untuk berkomunikasi secara tidak langsung, tidak secara tatap muka dengan orang lain. Dengan demikian karya tulis merapakan keterampilan berbahasa seseorang untuk menyampaikan gagasan dan berkomunikasi baik secara langsung maupun tidak langsung.

Penyusunan karya tulis dimaksudkan untuk menyampaikan hasil kajian, tulisan yang diperoleh secara empiris atau laporan.Selain itu, tujuan dapat juga dengan tujuan tertentu atau lebih khusus, sehingga dapat dimanfaatkan oleh pembaca.Adapun sasaran penulisan karya tulis untuk: (1) masyarakat atau bisa disebut juga para ilmuwan; (2) masyarakat secara menyeluruh, baik secara perorangan atau kelompok, dan (3) pemerintah atau lembaga pemerintah.

Karya tulis ilmiah adalah suatu karya tulis yang disusun berdasarkan pendekatan metode ilmiah (aplikasi 
dari metode ilmiah) yang ditujukan untuk kelompok pembaca tertentu dan disajikan menggunakan format tertentu yang baku. Metode ilmiah ini harus mengikuti prosedur dan langkah-langkah tertentu. Adapun langkah-langkahnya adalah sebagai berikut. 1). Mengidentifikasi masalah; 2). Menghubungkan masalah dengan teori tertentu; 3) Merumuskan kerangka konsepsional/teoritis; 4) Merumuskan hipotesis (bila diperlukan); 5) Menyusun rancangan studi; 6) Menentukan pengukuran dan teknik pengumpulan data; 7) Menganalisis dan menginterpretasi data; 8) Membuat kesimpulan. Dengan demikian aplikasi dari metode ilmiah tersebut dapat dikatakan sebagai suatu penelitian. Karya tulis ilmiah berupaya mengungkapkan secara jelas dan tepat mengenai masalah yang dikaji. Kerangka pemikiran dibuat untuk mendekati pemecahan masalah, mengapa dan bagaimana studidilaksanakan untuk memecahkan masalah, serta pembahasan hasil maupun implikasinya. Oleh karena itu, karya tulis ilmiah harus disusun secara logis dan terperinci berupa uraian teoritis maupun uraian empiris.

Pada penelitian ini yang dimaksud karya ilmiah adalah karya mahasiswa berbentuk Penelitian Tindakan Kelas (PTK) Pada Mata Kulia Penelitian Tindakan Kelas. Adapun Tujuan perkuliahan PTK pada Prodi PGSD di STKIP Kusuma Negara Secara umum, setelah mengikuti perkuliahan ini mahasiswa memiliki pengetahuan dan memahami konsep PTK, serta mampu mengaplikasikannya dalam bentuk penelitian di kelas guna memperbaiki proses dan hasil belajar. Adapun penilaian kemampuan menulis karya ilmiah mahasiswa pada penelitian ini mengembangkan penilaian tulisan dari Dwiyanto Djoko Pranowo (2005) 1) Struktur/Logika Penulisan;2)Kedalaman dan keluasan teori keilmuan yang relevan;3) Argumentasi teori dalam menyusun kerangka berpikir/penarikan kesimpulan;4) Orisinalitas;5) Relevansi teori dengan keahlian; 6)TeknikPengumpulan/keabsahaninstr ument/analisis Data, 7) Pembahasan danpenjabaran/ rincian \& saran, 8) Penyajiandan Bahasa.

Solusi dalam mengatasi permasalahan menulis siswa perlu diselesaikan. Adapun permasalahan tersebut di atasi dengan merancang suatu model pembelajaran atau menerapkan model pembelajaran. Model pembelajaran yang dimaksud adalah model pembelajaran yang memberikan kesempatan pada siswa untuk mengkonstruksi pengetahuannya sendiri, misalnya dengan memberikan kesempat-an siswa berinteraksi dengan teman. Selain itu, model pembelajaran yang mampu untuk melatih mahasiswa aktif, inovatif, produktif, dan kreatif agar memicu pola berpikirmahasiswa untuk menulis karya ilmiah dengan apik serta pembelajaran yang sesuai dengan aliran kontruktivisme. Secara garis besar prinsip-prinsip konstruktivisme adalah pengetahuan dibangun sendiri oleh mahasiswa Chrisnaji Banindra Yudha (2018:17). Dengan demikian, kemampuan mahasiswa dalam menulis akan lebih baik dan terjadi peningkatan. Dengan demikian, salah satu strategi yang dapat diterapkandosen sebagai alternatif dalam pemecahan permasalahan tersebut melalui ProjectBased Learning (PBL).

Pembelajaranseharusnya

dikemas secara efektif dan menyenangkan Dyah Anungrat 
Herzamzam (2018:19). Pembelajaran melalui PBL memiliki titik focus. Fokus pembelajaran terletak pada prinsip dan konsep inti dari suatu di-siplin ilmu, melibatkan siswa dalam investigasi pemecahan masalah dan tugastugas bermakna yang lain, memberi kesempatan siswa bekerja secara otonom dalam mengontruksi pengetahuan mereka sendiri, dan mencapai puncaknya untuk menghasilkan produk nyata.

Menurut Nanang Hanafiah dan Cucu Suhana (2009: 30) model pembelajaran Project Based Learning adalah pendekatan pembelajaran yang memperkenankan peserta didik untuk bekerja mandiri dalam mengkonstruksi pembelajarannya dan mengkulminasikannya dalam produk nyata. Sedangkan menurut Trianto (2014: 42) Project Based Learning adalah sebuah model atau pendekatan pembelajaran yang inovatif, yang menekankan belajar kontekstual melalui kegiatan-kegiatan yang kompleks. Menurut Made Wena (2014: 144) model pembelajaran Project Based adalah model pembelajaran yang memberikan kesempatan kepada guru untuk mengelola pembelajaran dikelas dengan melibatkan kerja proyek. Kerja proyek merupakan suatu bentuk kerja yang memuat tugas-tugas kompleks berdasarkan kepada pertanyaan dan permasalahan yang sangat menantang dan menuntun peserta didik untuk merancang, memecahkan masalah, membuat keputusan, melakukan kegiatan investigasi, serta memberikan kesempatan peserta didik untuk bekerja secara mandiri.

Dari beberapa pendapat dapat disimpulkan bahwa model pembelajaran Project Based Learning merupakan model pembelajaran inovatif yang melibatkan peserta didik bekerja secara mandiri dalam mengkonstruksi pembelajarannya dan mengkulminasikannya dalam produk nyata. Dalam kerja proyek memuat tugas-tugas kompleks berdasarkan kepada pertanyaan dan permasalahan yang sangat menantang dan menuntun mahasiswa untuk merancang, memecahkan masalah, membuat keputusan, melakukan kegiatan investigasi, serta memberikan kesempatan mahasiswa untuk bekerja secara mandiri.

Model PBL memiliki langkah pembelajaran yang diterapkan. Langkah-langkah pembelajaran dalam PBL sebagaimana yang dikembangkan oleh The GeorgeLucas Educational Foundation(2005) terdiri dari :

a. Start With the Essential Question

Pembelajaran dimulai dengan pertanyaan esensial, yaitu pertanyaan yang dapat memberi penugasan peserta didik dalam melakukan suatu aktivitas.

b. Design a Plan for the Project Perencanaan dilakukan secara kolaboratif antara pengajar dan peserta didik. Perencanaan berisitentang aturan main, pemilihan aktivitas yang dapat mendukung dalam menjawab pertanyaan esensial, dengan cara mengintegrasikan berbagai subjek yang mungkin,

c. Create a Schedule

(1) membuat timelineuntuk menyelesaikan proyek, (2) membuat deadline penyelesaian proyak, (3) membawa peserta didik agarmerencanakan cara yang baru, (4) membimbing 
peserta didik ketika mereka membuat cara yang tidak berhubungan dengan proyek, dan (5) meminta peserta didik untuk membuat penjelasan (alasan) tentang pemilihan suatu cara

d. Monitor the Students and the Progress of the Project Monitoring dilakukan dengan cara menfasilitasi peserta didik pada setiap proses.

e. Assess the Outcome

Penilaian dilakukan untuk membantu pengajar dalam mengukur ketercapaian standar, berperan dalam mengevaluasi kemajuan masingmasing peserta didik, memberi umpan balik tentang tingkat pemahaman yang sudah dicapai peserta didik

f. Evaluate the Experience

Pada akhir proses pembelajaran, pengajar dan peserta didik melakukan refleksi terhadap aktivitas dan hasil proyek yang sudah dijalankan.

Pendapat lain Menurut Rais (2010: 8-9) langkahlangkah model pembelajaran Project Based Learning adalah sebagai berikut: 1) Membuka pelajaran dengan suatu pertanyaan menantang (start with the big question) Pembelajaran dimulai dengan sebuah pertanyaan driving question yang dapat memberi penugasan pada peserta didik untuk melakukan suatu aktivitas. Topik yang diambil hendaknya sesuai dengan realita dunia nyata dan dimulai dengan sebuah investigasi mendalam. 2) Merencanakan proyek (design a plan for the project) Perencanaan dilakukan secara kolaboratif antara guru dengan peserta didik. Dengan demikian peserta didik diharapakan akan merasa memiliki atas proyek tersebut. Perencanaan berisi tentang aturan main, pemilihan aktivitas yang dapat mendukung dalam menjawab pertanyaan esensial dengan mengintegrasikan berbagai subjek yang mendukung, serta menginformasikan alat dan bahan yang dapat dimanfaatkan untuk menyelesaikan proyek. 3) Menyusun jadwal aktivitas (create a schedule) Guru dan peserta didik secara kolaboratif menyusun jadwal aktivitas dalam menyelesaikan proyek. Waktu penyelesaian proyek harus jelas, dan peserta didik diberi arahan untuk mengelola waktu yang ada. Biarkan peserta didik mencoba menggali sesuatu yang baru, akan tetapi guru juga harus tetap mengingatkan apabila aktivitas peserta didik melenceng dari tujuan proyek. Proyek yang dilakukan oleh peserta didik adalah proyek yang membutuhkan waktu yang lama dalam pengerjaannya, sehingga guru meminta peserta didik untuk menyelesaikan proyeknya secara berkelompok di luar jam sekolah. Ketika pembelajaran dilakukan saat jam sekolah, peserta didik tinggal mempresentasikan hasil proyeknya di kelas.4) Mengawasi jalannya proyek (monitor the students and the progress of the project) Guru bertanggungjawab untuk 
melakukan monitor terhadap aktivitas peserta didik selama menyelesaikan proyek. Monitoring dilakukan dengan cara memfasilitasi peserta didik pada setiap proses. Dengan kata lain, guru berperan sebagai mentor bagi aktivitas peserta didik. Guru mengajarkan kepada peserta didik bagaimana bekerja dalam sebuah kelompok. Setiap peserta didik dapat memilih perannya masingmasing dengan tidak mengesampingkan

kepentingan

kelompok.5)Penilaian terhadap produk yang dihasilkan (assess the outcome) Penilaian dilakukan untuk membantu guru dalam mengukur ketercapaian standar, berperan dalam mengevaluasi kemajuan masingmasing peserta didik, memberi umpan balik tentang tingkat pemahaman yang sudah dicapai oleh peserta didik, serta membantu guru dalam menyusun strategi pembelajaran berikutnya. Penilaian produk dilakukan saat masing-masing kelompok mempresentasikan produknya di depan kelompok lain secara bergantian.6) Evaluasi (evaluate the experience) Pada akhir proses pembelajaran, guru dan peserta didik melakukan refleksi terhadap aktivitas dan hasil proyek yang sudah dijalankan. Proses refleksi dilakukan baik secara individu maupun kelompok. Pada tahap ini, peserta didik diminta untuk mengungkapkan perasaan dan pengalamannya selama menyelesaikan proyek.
Dengan demikian
pendekatan Project Based Learning dapat digunakan sebagai alternatif pemecahan masalah dalam rangka peningkatan keberhasilan pendidikan.

(2014: Menurut Made $\begin{gathered}\text { Wena } \\ \text { 147), }\end{gathered}$ pembelajaran project based learning mempunyai beberapa kekurangan dan kelebihan sebagai berikut : 1) Kelebihan Model Pembelajaran Project Based Learning a) Meningkatkan motivasi b) Meningkatkan kemampuan pemecahan masalah c) Meningkatkan kolaborasi d) Meningkatkan keterampilan mengelola sumber e) Increased resource - management skill. Selain itu, Neumont University (2006) melaporkan hasil riset yang dilakukan oleh National Training Laboratory tentang model pembelajaran yang melibatkan mahasiswa untuk saling berperan aktif dalam proses pembelajaran sebagaimana yang dikembangkan dalam Project Based Learning sebagai berikut : research shows that we retain significantly more ofwhat we learn when we learn by doing or from teaching others thanwe retain when we learn from lectures or from reading, Pendapat lain. Pendapat lainMenurut Buck Institute for Education (Samanthis \& Sulistyo, 2014:25), project based learning (PBL) memberikan pengalaman belajar yang detail, rinci, menantang, dan dalam jangka waktu yang lebih 
panjang dengan target terselesaikannya proyek yang menghasilkan sebuah produk, karya siswa yang memuaskan. 2) Kelemahan Model Pembelajaran Project Based Learning a) Memerlukan banyak waktu yang harus diselesaikan untuk menyelesaikan masalah. b) Memerlukan biaya yang cukup banyak. c) Banyak peralatan yang harus disediakan.

Roessingh dan

Chambers (2011, p.60) mengemukakan bahwa elemen penting dalam desain proyek yaitu, (1) gambaran proyek dengan rasionalisasinya, (2) seperangkat tujuan pembelajaran yang jelas dan konsepkonsep kunci, (3) daftar bahan dan sumber daya, (4) memungkinkan seperangkat tugas, dan (5) kriteria penilaian dan rubrik.

Bagian akhir dari implementasi PBL adalah melakukan evaluasi dan pengetesan terhadap kompetensi siswa. Berkaitan dengan hal ini, Miller (2012) memberikan beberapa saran penerapan standar tes dalam PBL, yaitu (1) jangan menunggu, maksudnya guru tidak perlu menunggu hingga akhir proyek untuk melakukan tes atau penilaian. Tes dapat dilakukan selama proses belajar berlangsung; (2) Kekuatan standar/target pembelajaran, maksudnya ketika guru merancang proyek PBL, pastikan standar tes sesuai dengan target pembelajaran; (3) Implementasi PBL yang sempurna, maksudnya pengetesan atau evaluasi dapat dilakukan pada implementasi PBL yang sempurna. Proyek yang dilaksanakan tanpa kendali akan sulit untuk diterapkan standar tes yang baik dan evaluasi menyeluruh.

Dari hasil riset yang dilakukan oleh National Training Laboratory di atas terbukti melalui kegiatan dengan peran langsung oleh mahasiswa dapat berpengaruh signifikan terhadap diri mahasiswa tersebut. Selain itu menurut I Ketut Turyantana (2013.p.i) Hasil penelitian ini adalah (1) tercapainya ketuntasan hasil belajar menulis karya ilmiah siswa berkat diterapkannya model pembelajaran berbasis proyek, yakni pada pratindakan skor rata-rata klasikal 67 , siklus I memperoleh skor ratarata klasikal 70, sedangkan pada siklus II nilai rata-rata klasikal siswa menjadi 79, (2) siswa terlihat aktif dalam melaksanakan kegiatan pembelajaran, (3) terdapat beberapa langkah penerapan model pembelajaran berbasis proyek untuk meningkatkan aktivitas dan tercapainya ketuntasan hasil belajar menulis karya ilmiah.

Dengan demikian dari penelitian terdahulu tersebut, maka yang menjadi kebaruan penelitian ini adalah penerapan PBL di tingkat mahasiswa PGSD, dimana penelitian ini masih langka untuk dilaksanakan pada mata kuliah penelitian tindakan kelas di jenjang perguruan tinggi. 
rumusan penelitian ini adalah kemampuan menulis karya ilmiah mahasiswa melalui penerapan model projectbased learning pada mata kuliah penelitian tindakan kelas?
Tujuan penelitian ini adalah meningkatkan kemampuan menulis karya ilmiah mahasiswa pada mata kuliah penelitian tindakan kelas melalui model project based learning.

\section{METODE}

Jenis Penelitian dalam adalah melalui Observasi dan penelitian ini adalah penelitian Wawancara.Menurut Parjono, dkk tindakan kelas (classroom action (2007: 43), Teknik observasi research).

Pelaksanaan Penelitian

dilaksanakan dari Bulan Februari sampai dengan Bulan Juni Tahun 2019 adapun Tempat Penelitian ini di Prodi PGSD STKIP Kusuma Negara Jakarta .

Subjek Penelitian ini adalah semua mahasiswa prodi PGSD STKIP Kusuma Negara Kelas 6Bsebanyak 25 orang.

Prosedur tindakan yang diterapkan, mengacu pada aspek pokok penelitian tindakan kelas model (Kemmis dan Mc Taggart, 1988, p.11) yaitu perencanaan, pelaksanaan, observasi, dan refleksi.

Tindakan dalam penelitian ini dilakukan dalam dua siklus.Adapun masing-masing siklus menerapkan langkah-langkah PBM yaitu (1) Start With the Essential Question, (2) Design a Plan for the Project. (3) Create a Schedule, (4) Monitor the Students and the Progress of the Project, (5) Assessthe Outcome, (6) Evaluate the Experience.

Validitas yang digunakan dalam penelitian ini adalah validitas isi (content validity). Validitas isi instrumen mengacu pada sejauh mana item instrumen mencakup keseluruhan situasi yang ingin diukur.

Intrumen pengumpulan data yang digunakan dalam penelitian ini merupakan teknik monitoring yang dilakukan denganmelakukan observasi/pengamatan terhadap sasaran pengukuran, dengan menggunakan lembar pengamatan atau lembar observasi yang telah dipersiapkan sebelumnya. Observasi dalam penelitian ini dengan cara melakukan pengamatan langsung dan pencatatan mengenai pelaksanaan pembelajaran di kelas perkuliahan.Teknik Wawancara atau interview, merupakan teknik memperoleh data dengan mengadakan dialog langsung dengan subjek yang akan dinilai, Pardjono, dkk (2007: 42).Wawancara ini diperlukan untuk memperoleh suatu umpan balik dari proses pembelajaran yang sudah berlangsung, yang selanjutnya dijadikan sebagai dasar untuk menyusun tindakan dalam merencanakan pengelolaan pembelajaran pada tahap berikutnya.

Teknik analisis data pada penelitian ini adalah analisis diskripsif kualitatif, dalam hal ini yang dimaksud adalah instrumenwawancara. Analisis yang diperoleh dideskipsikan kemudian diambil kesimpulan. Selanjutnya menggunakan analisis diskriptif kuantitatif untuk instrumen observasi.

Proses analisa data pada penelitian ini sesuai model Miles and 
Huberman (Sugiyono, 2006, pp. 337345), yaitu langkah-langkah analisis data terdiri dari tiga alur kegiatan secara bersamaan antara lain: reduksi data, penyajian data, dan kesimpulan.

$$
\text { Pengumpulan Data hasil }
$$
observasi dilaksanakan oleh peneliti dan kolaborator. Observasi dilaksanakan pada saat tahapan pelaksanaan penelitian. Pernyataan dalam pedoman observasi mempunyai dua alternatif jawaban, yaitu YA atau TIDAK serta dipertegas melalui keterangan. Apabila dipilih jawaban YA maka mendapatkan skor 1 dan apabila TIDAK maka mendapatkan skor 0 , selanjutnya dihitung presentasenya menggunakan rumus menurut (Eko Putro Widoyoko, 2012, p.110) sebagai berikut:
Persentase Skor $(P)=\frac{\text { skoryangdiperoleh }}{\text { skormaksimal }} \times 100 \%$

Data kualitatif diambil dari hasilwawancara yang telah dilaksanakan. Wawancara dilaksanakan oleh observer. Observer mencatat dan menggali data melalui wawancara pada tiap-tiap mahasiswa. Pelaksanaan wawancara sesuai dengan pedoman wawancara tak terstruktur.

Kriteria keberhasilan pada penelitian ini dilihat dari segi kemampuan menulis karya ilmiah adalah sebesar $80 \%$. Hal ini sesuai dengan aspek atau indicator kemampuan menulis karya ilmiah.

\section{PEMBAHASAN}

Dari penelitian yang telah dilaksanakan, diperoleh hasil penelitian tentang kemampuan menulis karya ilmiah mahasiswa. Pada saat pra pelaksanaan proses pembelajaran menggunakan PBLmahasiswa mempunyai tingkat kemampuan menulis karya ilmiah yang rendah. Hal ini dapat dilihat saat dosen mengkroscek proposal penelitian tindakan kelas masingmasing mahasiswa. Mahasiswa dalam menyusun proposal PTK tersebut, belum ditemukan Struktur/Logika Penulisan yang jelas; dalam mengkutip teori, Kedalaman dan keluasan teori keilmuan yang relevan tidak tampak dan terkesan pada bagian teori adalah kumpulan teoriteori yang tidak ada hubungannya dengan judul proposalnya ; dalam menyusun Argumentasi teori untuk menyusun kerangka berpikir belum sesuai dengan alur ptk;dikarenakan banyak sumber yang tidak dituliskan, terkesan Orisinalitas tulisan PTK mahasiswa yang rendah;mahasiswa belum terlihat dalam mengutip teori yang relevan dengan bidang PTK yang dimiliki. Dalam menyusun

TeknikPengumpulan/keabsaha ninstrument/analisis Data, sebagian besar mahasiswa yang tidak sesuai dengan apa yang akan dilihat atau diukur. Dalam memberikan Pembahasan belum mampu untuk memberikan penjelasan yang secara terstruktur, hubungan proposal dengan teori yang dikutip serta alat atau instrument penelitian yang akan digunakan, belum mampu untuk menyusun kisi-kisi atau aspek-aspek yang akan menjadi tolak ukur penelitian. Oleh karena itu, dilaksanakan penelitian dengan menerapan PBL untuk meningkatkan kemampuan menulis karya ilmiah mahasiswa. Selama siklus 1 dan siklus 2 penelitian menunjukan hasil sebagai berikut: 
Tabel 1. Persentase Peningkatan Kemampuan Menulis Karya Ilmiah Mahasiswa

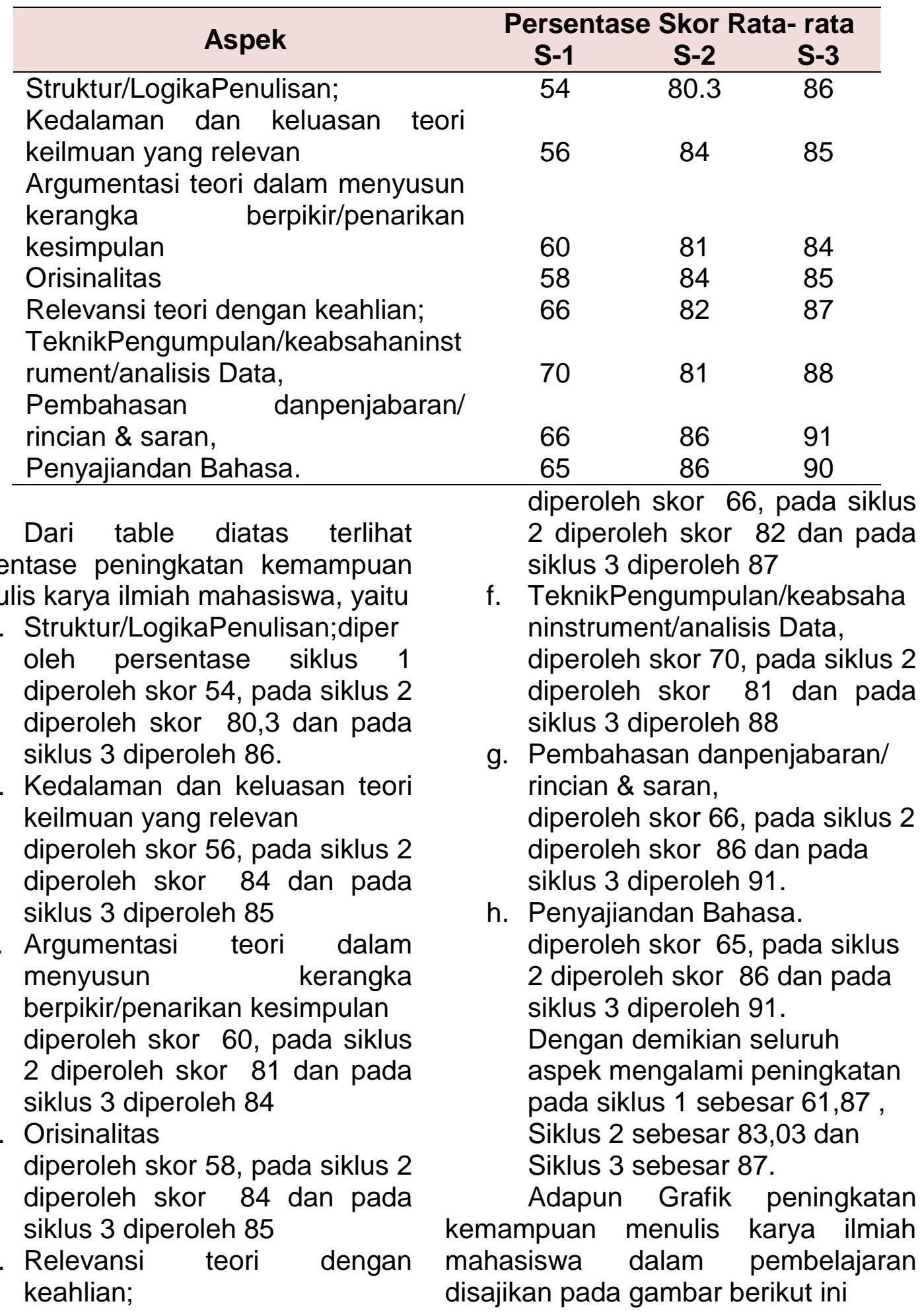




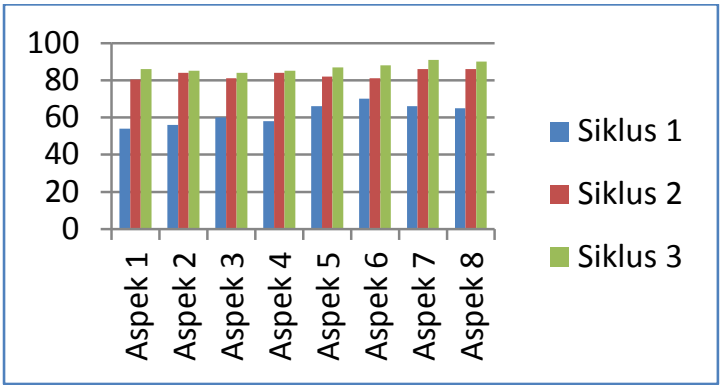

\section{Gambar 1. Peningkatan Kemampuan Menulis Karya IImiah Mahasiswa}

Temuan penelitian menunjukan bahwa (1) yang menyangkut peningkatan kemampuan menulis karya ilmiah mahasiswa dengan penerapan model PBL adalah Penerapan model pembelajaran berbasis proyek mampu meningkatkan kemampuan mahasiswa menulis karya ilmiah. Hal ini terlihat dari peningkatan rata-rata yang diperoleh

mahasiswa.seluruh oleh penelitian mengalami peningkatan pada siklus 1 sebesar 61,87 , Siklus 2 sebesar 83,03 dan Siklus 3 sebesar 87. (2) aktivitas belajar mahasiswa cenderung lebih aktif dalam PBL, Hal ini karena para mahasiswa memiliki tanggung jawab masing-masing untuk menyelesaikan PTK nya. (3) mahasiswa menjadi enjoy dalam pembelajaran menulis Makalah (PTK). Hal ini merupakan temuan penting terakhir dalam penelitian ini. dapat dilihat dari respons yang diberikan oleh siswa dalam pembelajaran ini melalui wawancara tidak langsung oleh peneliti

\section{SIMPULAN}

Berdasarkan hasil analisis dan pembahasan penelitian dapat disimpulkan bahwa penerapan PBL dalam pembelajaran menggunakan PBL dapat meningkatkan kemampuan menulis karya ilmiah mahasiswa. Peningkatan tersebut diperoleh melalui tindakan PBL dengan tahapan

(1) Start With the Essential Question,

(2) Design a Plan for the Project. (3) Create a Schedule, (4) Monitor the Students and the Progress of the Project, (5) Assess the Outcome, (6) Evaluate the Experience.

Peningkatan tersebut tercermin pada kemampuan mahasiswa dalam menuliskan karya ilmiahnya. Hal ini dibuktikan rata-rata persentase aspek atau indicator kemampuan menulis karya ilmiah. Pada siklus 1 sebesar 61,87, Setelah dilakukan perbaikan proses belajar Siklus 2 meningkat sebesar 83,03 dan konsistensi peningkatan pada Siklus 3 sebesar 87. Dengan demikian Kemampuan mahasiswa dalam menulis karya ilmiah telah mencapai lebih dari $80 \%$.

Mencermati hasil penelitian yang ditemukan, maka saran disampaikan kepada beberapa pihak berikut. (1) mahasiswa: kemampuan dalam menulis karya ilmiah sudah meningkat. Oleh karena itu perlu dipertahankan untuk peningkatan kualitas mahasiswa. (2) Dosen: serangkaian proses pembelajaran 
PBL dijadikan referensi dan diterapkan, akan tetapi disesuaikan dengan kecocokan materi, selain itu untuk pengembangan diri dalam perbaikan proses pembelajaran. (3) Program Studi: PBL diterapkan pada semua kelas dengan dipertimbangkan kecocokan materi. Penelitian ini bermanfaat untuk mahasiswa yaitu mahasiswa memiliki sikap positif terhadap pembelajaran menulis karya ilmiah, mahasiswa mampu merancang penelitian untuk penyelesaian skripsi sebagai syarat kelulusan dan Dosen mempermoleh umpan balik dari pembelajaran yang dilaksanakan, maka dapat dijadikan rujukan untuk penelitian berikutnya.

\section{DAFTAR PUSTAKA}

Azril Azahari. 2013. Teknik Penulisan Karya IImiah: UT: Jakarta

Chrisnaji Banindra Yudha. 2018. Peningkatan Motivasi Belajar Mahasiswa Pada Mata Kuliah Konsep Dasar Matematika Melalui Pendekatan Contextual Teaching And Learning. Jurnal Pendidikan Dasar Volume 9, Nomor 1, 2018, Pascasarjana Universitas Negeri Jakarta

Dalman. 2014. Keterampilan Menulis. Jakarta: PT RajaGrafindo Persada.

Dwiyanto Djoko Pranowo. 2005. Peningkatan Motivasi Menulis melalui Penilaian yang Berkeadilan. Makalah disampaikan dalam seminar nasional PIBSI XXVII, 27-28 September 2005, Jur. PBSI FBS UNY.

Dyah Anungrat Herzamzam.2018. The Effectiveness Of Educational Games In Math Learning In Elementary School. Dwija Cendekia: Jurnal Riset Pedagogik 2 (2) (2018) 21-25.

I Ketut Turyantara. 2013. Penerapan model pembelajaran berbasis proyek Untuk meningkatkan aktivitas dan tercapainya Ketuntasan hasil belajar menulis karya ilmiah Siswa kelas XI IPS 1 SMA Saraswati Seririt. Singaraja: Undiksha.

Made Wena. 2009. Strategi pembelajaran inovatif kontemporer: suatu tinjauan konseptual operasional. Jakarta: Bumi Aksara.

Miller, A. 2012. PBL and standardized tests? it can work! Diakses pada 28 Juni 2019. dari: http://www.edutopia. org/blog/PBLandstandardizedtestsandrewmiller

Muh. Rais. 2010. Project based learning: Inovasi pembelajaran yang berorientasi soft skills. Makalan disajikan sebagai Makalah Pendamping dalam Seminar Nasional Pendidikan Teknologi dan Kejuruan Fakultas Teknik Universitas Negeri Surabaya Tahun 2010. Surabaya: Unesa.

Nanang Hanafiah \& Cucu Suhana. 2009. Konsep strategi pembelajaran. Bandung: PT. Refika Aditama.

Neumont University.2006.Project Based Learning. Diakses pada Tanggal 28 Juni 2019 dari http://www.neumont.edu/futurestudents/bachelor-projectbasedlearning.html I 
Roessingh, H. \& Chambers, W. 2011.

Project-based learning and pedagogy in teacher preparation: staking out the theoretical

MidGround.International

Journal of Teaching and Learning in Higher Education, Volume 23 (1).

Samanthis, A. \& Sulistyo, E. 2014. Pengembangan perangkat pembelajaran menggunakan model Project based learning pada Standar Kompetensi memperbaiki Radio Penerima di SMKN 3 Surabaya.

Tarigan, H.G. 2013. Menulis Sebagai Suatu Keterampilan Berbahasa. Bandung: Angkasa

The George Lucas Educational Foundation.2005. Instructional Module Project Based Learning. Diakses pada Tanggal 28 Juni 2019 darihttp://www.edutopia.org/mo dules/PBL/whatpbl.php

Trianto Ibnu Badar Al-Tabani. 2014. Mendesain model pembelajaran inovatif, progresif, dan kontekstual. Jakarta: Prenadamedia Group.

Wajdi .2014. Implementasi project based learning. Jurnal Pendidikan Teknik Elektro, Volume 03, (01), Tahun 2014.

Widoyoko, E.P. 2011. Teknik penyusunan instrumen pendidikan. Yogyakarta: pustaka pelajar. 